\title{
Wulf Sachs, race trouble, and the will to know
}

\author{
[ B R I E F I N G ]
}

The subtitle indicates that Wulf Sachs' Black Hamlet (1937) is an expose: "The Mind of an African Negro revealed by Psychoanalysis". The book is a psychobiography of John Chavafambira, whom Sachs describes as a "witch-doctor" who travelled to South Africa from a "kraal in Southern Rhodesia", eventually taking up residence in Johannesburg. Sachs seeks to show the universality of the human mind. Although context, culture and "civilization" shape the superficial content of beliefs, motivations and delusions, Sachs "discovered" that "the manifestations of insanity, in its form, content, origins, and causation, are identical in both natives and Europeans." ( $p$ 11)

In this essay, I will consider what Black Hamlet reveals about the mind of a progressive white man living in South Africa in the 1930s - and, by extension, today. There can be no doubt that his work and close association with black people, including his visits to the Swartyard - an inner city black slum - and various rural kraals, must have cast Sachs as an outsider to white society at the time. Sachs was a progressive and he has been described both as a white "liberal" and as a "socialist" (Bloom, 2004).

\section{The will to know}

What is the impetus behind this will to know: the impulse to reveal the mind of the black man? Black Hamlet is certainly an academic exercise. It is the product of a rigorous examination of the subject matter. Sachs' methodology is evident in his interrogation of John concerning the twins who were found murdered in Swartyard. John explained that the twins were killed

\section{Kevin Durrheim}

Psychology, School of Applied Human Sciences, University of KwaZulu-Natal, Pietermaritzburg 
because the Manyika people regarded twins as "coming from two fathers, one of whom is a snake, a sorcerer, or some other evil-doer" ( $p$ 153). Then Sachs' commences his interview:

"Describe, John, how the killing is done. What medicine do they use? And I want to know whether they pray. Do they drink beer? How is the mother dressed? Is the killing done inside the house or outside? Are the babies washed first? How are they prepared? Does the mother really go to the river and allow the twins to drop off her back, and then run away?" (pp 153-4)

Sachs' report aspires to be a museum piece. It is an uncovering of African culture and the black man that has its place in a colonial tradition of scholarship (Denzin \& Lincoln, 1994). It is an attempt to render the strange familiar; and to domesticate the wild and unknown. It is undertaken from the elevated point of view of Science, a perspective that reinvents its own authority as it demystifies the other:

"The European generally believes a witch-doctor to be possessed by some mysterious knowledge concerning potent and magic roots: this certainly does not apply to John. He had no knowledge of any single medicine he used ..." ( $p$ 155)

"John's technique depended very much upon his quick grasp of the patient'strouble, and to a certain degree of the symbolism of the bones... After witnessing a number of sessions I soon found myself as proficient a witch-doctor as he, and to his delight and amazement I proved it to him on several occasions, with the advantage, of course, that my medical knowledge of the case and a deeper psychological insight than John's helped me to obtain from the bones a more correct interpretation than his." (p 159)

"The European conception of fate was unknown to John. His explanation of the causes of suffering was more concrete. These causes emanated from ancestral spirits and sorcerers. So John recognized a concrete cause for his troubles; a cause that existed, not in himself or external life, but in a world which Europeans would call supernatural. Yet to him the supernatural world was real and natural. He could fight these causes only by means of magic and the performance of rites." ( $p$ 163)

In the end, by this process of translation and appropriation, the African's knowledge is shown to amount to very little indeed. The "witch-doctor" knew nothing about the medicines he used. In this magical "order of things" (Foucault, 1971), his technique was restricted to a reading of the signs and surfaces of things. As such, they were easy for Sachs to learn, and he could do a better job at being a witch-doctor with 
his added advantage of "deeper psychological insight". The encounter between the two systems of knowledge is done in the terms of one, and on its terms. African knowledge is laid out in tableau as an object of European knowledge, which itself is inscrutable to the African.

This places Sachs in a position to help John, just as an analyst can help a patient by diagnosing underlying causes of their behaviour. His analysis allows Sachs to help John to understand the real causes of his problems. John's Hamletism - his overly indecisive and passive nature - arises, not because he is oppressed by the racist world he lives in, but because of an error of attribution. Believing as he does that the supernatural world is real and natural, he identifies external and concrete causes for his troubles, rather than taking responsibility for and charge of his life.

Thus Sachs deploys knowledge in the interests of care and rehabilitation. This strategy can help the European acquire a sense of humanity in an inhumane, unjust and brutal world that benefits him at every turn. Such understanding-based-kindness was evident in the Defence's arguments in the trial of Mdlawini, "a raw, illiterate native" ( $p 213$ ), who had murdered a young man whom he believed was a ghost out to harm him.

"To the primitive African, the belief in witchcraft is real and logical. There is no such thing as imaginary feeling ... The African fears malicious spirits that he actually sees and hears. He lives in constant fear and turns to witch-doctors, in whom he places unconditional belief and trust. Mdlawini had a reasonable belief in evil-doers. That evil spirits were acting against him, as he first intuitively guessed, was definitely confirmed by the woman [witch-doctor], and by another witch-doctor. Certainty brought terror and fear, and prompted him to take desperate measures ... Civilized people find it extraordinarily difficult to get away from our way of thinking, and therefore find it hard to grasp what is going on in the mind of the man whose ways of thinking and acting are foreign and almost unintelligible to us." (pp 219-220)

From the point of view of an irrational worldview, Mdlawini's actions were eminently reasonable. Don't use your outside criteria and elevated world view to judge, argues the Defence in the trial, show compassion for the poor man, the primitive African. Can't you understand his motives, his fear and terror? Get away from your civilized way of thinking. He is human like you. Try understand the feelings that might lead someone to resort to such desperate measures.

\section{Race trouble}

Knowledge of this kind shores up white supremacy, but one can't help feeling that there are also more personal motives at play. Just as the brutality of the police's interrogation 
of the twins' murder reveals their racism, doesn't Sachs' humane questioning, diagnosis, and empathetic understanding say something about Sachs himself? The possibility that the exercise of revealing the mind of the Native serves personal self-managing functions is suggested by John's remark, recorded by Sachs (on page 200): "I can see that you, Doctor, love the natives. You want to know how they really live and what they think".

Throughout the book, Sachs is troubled by the representations that John and other black people he comes in to contact with might have of him. This is the problem of being white. Race trouble. There is the suspicion that, like it or not, black people think you are racist (Durrheim, Mtose \& Brown, 2011).

"I knew him to be involved in severe inner conflict and understood his hatred and bitterness towards me and all white people, though he himself said nothing." ( $p$ 154)

"Never trust the white man. He is like a puff-adder in the dust, that strikes backwards." (p 154)

"I explained to him the essence of the aggressive instinct, of the necessity and unavoidability of hating people whom we believed to be hostile to us ..." ( $p$ 155)

Sachs' experience of race trouble as guilt is narrated in a powerful chapter in which three of John's companions visited Sachs to discuss John's arrest: Tembu, an "educated African" who frequented the Bantu club; Simon, John's companion from the Swartyard, who lived a "life of orgy and drink"; and an unnamed "coloured man". The conversation is polite. It is a civil exchange in which the four men - three black and one white - consider how they can help John, their friend. Sachs, however, comes away deeply disturbed:

"Tembu's last remark irritated me. There was no need to instruct me on my duties to my fellow-men: I, of all people, who had constantly proclaimed my deep interest in the natives. Indeed, I had even been victimized because of this interest. I had been compelled to leave a consulting room in a fashionable block of flats, outwardly on some trivial pretext, but actually I suspected because John and other natives came often to visit me there." ( $p$ 224)

"Judges never understand the men they try, I told myself, and then caught at the word. Try? ... Yes - I was on trial now. The coloured man, silent, lifeless, with a masked face, appeared to be the judge; Tembu, vindictive and inwardly aggressive, the prosecutor; and Simon, the simpleton, the jury. Was I to place myself in the hands of these hostile men and protest to them my innocence? Didn't I myself, a Jew, belong to a people ceaselessly driven from pillar to post? It is useless telling them so.

PINS [Psychology in Society] 51 • 2016|102 
They wouldn't understand me ... Yet, John must be saved, but how? With these men watching me, silently judging me ..." (p. 226)

"Did they believe me to be a real friend of the Africans and honest with my relations with John? Would they trust me absolutely if I declared myself to be prepared to do anything to save John.” ( $p$ 231)

The answer Sachs receives to his final question about whether he is trusted is "No". $\mathrm{He}$ is a white man. No matter what he says or does, the weight of racist exploitation and the brutality by which whites rob blacks of dignity makes it impossible. Despite his protestations, Sachs is implicated and benefits from this system as much as the next white man.

Sachs knows this too. He wants an exception to be made: He is a Jew. He has a deep interest in the natives! He too has been victimized by white society. He wants to be a real friend of the African. He really wants to help. How unfair too that he be put on trial. He wants the judge, jury and prosecutor to understand him, just as he understands John and Mdlawini. However, Sachs' compassion for himself soon gives way to anger. He is irritated. How dare these men then instruct him or judge him.

Doesn't Sachs protest too much? Isn't his compassion for himself and his irritation at his accusers informed by an underlying sense of guilt? Perhaps he had been using John to service his own selfish ambitions. This possibility is suggested by the following passage in which Sachs answers his self-accusation.

"I tried to console myself by reminding myself that I was not responsible for John's downfall. I had done everything possible for him. He had reverted to witchcraft because his one ambition in life was to become like his father, a witch-doctor; and no effort of mine could prevent him. Neither could I change the attitude of the white people towards the black. Fear ... it was a question of terrible fear: the fear of the blacks for the whites; fear that dominated the whole of South Africa. How could I, one small individual, root up the curse of humanity." (pp 225-6)

We can learn a lot about how race trouble can be managed by Sachs' exoneration of himself. Previous research has shown how white employers of domestic workers manage race trouble by caring, helping and generously giving favours to their workers; and by cultivating intimate and friendly relations with them (Durrheim, Jacobs \& Dixon, 2014).

Sachs' writings suggest that guilt may be quelled by explanation. Insight into the mind of the African Negro allows Sachs to understand how John is himself to blame for his 
predicament. He also understands the terrible fear of white people which explains his own impotence, indecision, and inability to challenge the racism of his world and his position within it.

Helping, however, only takes you so far in a system of oppression where help does not change the material conditions of the life of the subaltern, and where white privilege remains intact and defines one's relationships. One also needs to explain the difference. Then the consolation of care must be supported with the comfort of knowing that you are not to blame.

\section{References}

Bloom, L (2004) "Black Hamlet”: A psychoanalyst destrangers a stranger.

PINS (Psychology in society), 30, 35-41.

Denzin, N K \& Lincoln, Y S (1994) Introduction: Entering the field of qualitative research, in Denzin, N K \& Lincoln, Y S (eds) Handbook of qualitative research (pp 1-17). Thousand Oaks, CA: Sage.

Durrheim, K, Jacobs, N \& Dixon, J (2014) Explaining the paradoxical effects of intergroup contact: Paternalistic relations and system justification in domestic labour in South Africa. International Journal of Intercultural Relations, 41, 150-164. http://dx.doi.org/10.1016/j.ijintrel.2013.11.006

Durrheim, K, Mtose, X \& Brown, L (2011) Race trouble: Race, identity and inequality in post-apartheid South Africa. Pietermaritzburg: University of KwaZulu-Natal Press.

Foucault, M (1971) The order of things: An archaeology of the human sciences. New York: Pantheon (1966-French).

Sachs, W (1937) Black Hamlet: The mind of an African Negro revealed by psychoanalysis. Manchester: Geoffrey Bles. 